\title{
実験的粲性高血压にお计る压受容体の関与
}

\author{
東京大学医学部吉利内科教空（指尊 吉利 和教授） \\ 山肾吾

\section{THE ROLE OF BAROCEPTORS IN EXPERIMENTAL RENAL HYPERTENSION} \\ Yogo Yamanaka
}

The First Department of Internal Medicine, Faculty of Medicine University of Tokyo

(Director: Prof. Y. Yoshitoshi)

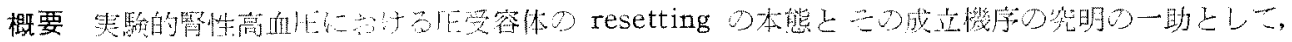

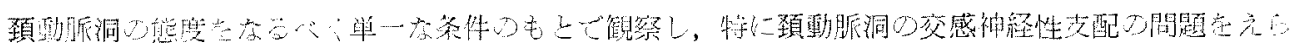

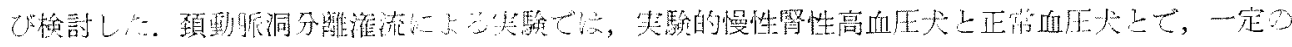

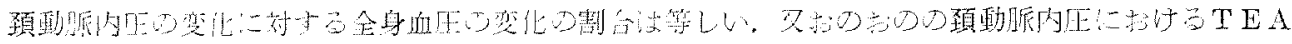

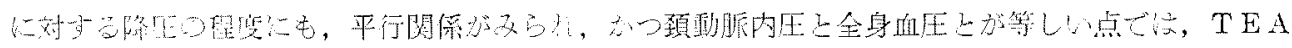

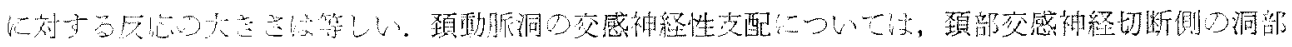

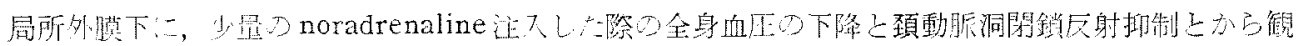

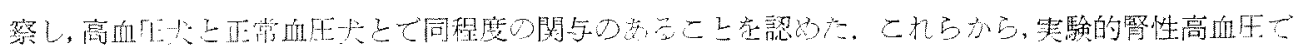

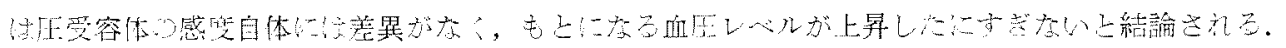

\section{緒言}

腎上高血比上の関係については, Richard Brightの記戴にはじまるが、この再者の関係に関 する実験的試みは、前世紀末以後のことである。 1898年, Tigerstedt とBergmanが正常家雸腎抽出 物を正常家䨘に注射し，血圧の上㫤することを認 わ，二れをreninと名づけた。二狆は留性早王物 質にかんしての最初の記載であり，貴重な業績で あつたが，1934年Goldblattによる実駼的腎性高 血在作成の成功恙で，一㭙かえりみられ李かつた 感がある.Fahr (1925) は，㷂虚血モのものが 高血生の進展に重要高㪀割を湍じていることを暗 示し、この考元のもとにGoldblattら ${ }^{1)}$

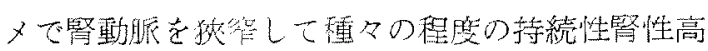
血压犬の作成に成功し，ついで二机を広く腎の 血行動熊の变化によるもの上する考えから, Page

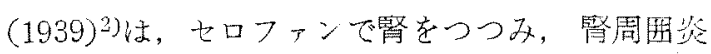

本諭交の要旨は鹳25回日本循環器学会總会にて発素 した. (cellophane perinephritis)をちこし，持続性高血

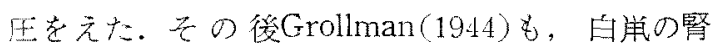

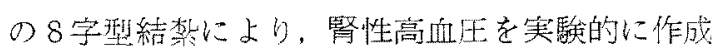
した.

Goldblattは，臂動脈㷋管による実験的高血圧と reninとの関係に注目し，以後婜性景圧物䁈を中心 とした，高血压の体液性メカニズムにかんする研 究が，広く行なわ礼るようになつた。特にBraunMenendez, Pageによるangiotensinの発見は, そ の生北学的研究に扔汀重要な一階程己なつた。

腎性高血圧の発生機序家考えるに当つては，一 方に昇王物質の側の間題上，他方生体側の反地性

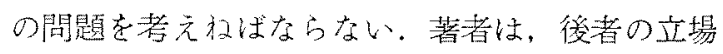
から主としてこの問題を考え, 特に王受签体のし める径割を中心上して検討した。

頝動脈洞にかんする研究の歴史をみる之，1836 年Cooperが，雨側総頚動脈の瓜迫によつて頭部 の血圧の下降, 心拍数の增加, 全身血压の上昇を みて以来, 頝動脈洞の王迫による影響, 頝動脈洞 
の機能及び血王調節ないしは高血圧の維持に対す る役割にいたるまで，多くの業績がなされてき た. 頝動脈内生の変動によつて, 全身血圧と心拍 数の变化をきたすことは，最初に血流の变化によ る血管運動中枢一の直接の影響と考えられていた が，その後，圧受容体の存在が明らかにされて， 血圧は在受容体に対する動脈压そのものの作朋に よつて，反射的に調節されることが示されたい．

実験的筑性高血汪においては，初期の血王上景 期, 即占急性期をいて, 後の長期にわたる慢性期 ができるが，従来この雨時期の間には，一般に， その基整的メカニズムに差があると考无ら机，急 性期には主として体液性機楎孞，後の慢性期の血 㞋の維持には主として神督性機棈が関与すると考 えられてきた。この神経性機構の関与については, 上昇した血王レベルに対して，なぜ压受容体が反 応しないかという問題が焦点となつているが，実 験的蛗性高血王に㧍ける氐受容体の関与を検㑏す る意味もここに存在する。

慢性亚性高血正では，高血压の過程において， 殴受容体の反応するもとのレベルが高い血印レベ ルに“ set”される。即ち压受容体のresettingが

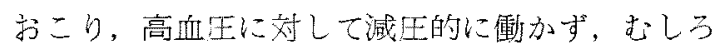
維持する傾问をもつ上する考え方有力であり，多 くの成續が示されている。

著者は，頝動脈洞の慢性腎性高血圧に方ける区 灾の態度をなるへく単一条条件のもとでるる と，文ざ頊動脈洞の交感神経性関与についてはさ きに示されたすが，この交換神経支配の様相が， 高血厈で变つていないかどうかをみることを主た る目的として検討した。

\section{実験方法}

1）寒験的筒性高血圧犬の作成

大は体重 $10 \mathrm{~kg}$ 前徣から $15 \mathrm{~kg}$ にいるる雑種成大を 用い, Goldblatt ${ }^{1)}$ 法に集じた一側婜勘脈のクレン メによる狄窄と，7〜10日後の他側腎摘による力 法抒よびPage2ンのセロファン（Du Pont製）包被 による一側婜周用炙と，7〜10日媵の他側筒摘に よる方法にて，実験的腎性高血死を作成した。
第 2 回目の腎摘手術は腹部正中勿開にて行ない, Goldblatt法では前回の腎县脈狄㻍が道切であつ たかどうか，肉眼㧍よび触診にて観祭し，不充 分の場合は再度狹管を行在つたものが一部亦つ

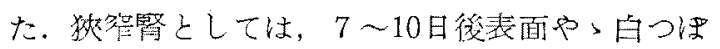
く，や〉硬めで，大きさもごくわずか小さくなつ ている程度が適当であつた，Page洼では，七口 ファンの艄落がないかどうか確かめた。著者の行

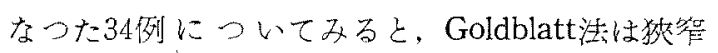
をおこさせる程苃が，個々の大で，婜の大きさ， 腎動脈の太さ等记応じて，適当に調節せねばなら ず，徒つて，しめずきしいたりぬための不成功 例がや〉多く，二の点Page法は技術的には容易 であり，成功就が高い，即ち，Goldblatt法では14 例中成功例 5 例に対し, Page法では17例中12例に

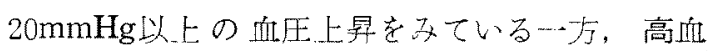
圧に達するまでの期聞洁，Page法の方がや>長い ように思わ饥る。即ち，Goldblatt法で2〜6週で あるが，Page法では3〜8週を瑟していた。

2) 大の血王測定法

くり返してたの血在党測定する場合必要なこと

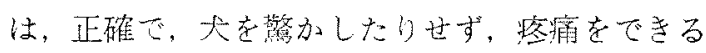
だけ少なくして，想麻酔て行なうことであるう。 犬の大戌は四錐状なので，Riva-Rocci法で間接的 に测定することは困蜼でる。次に，carotid loop を用いる方法であるが，难動脈洞神経を切除せ

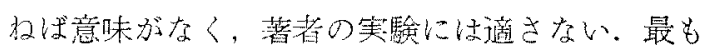
満足すべき方法は，犬をよく馿らして，大腿動脈 加直接法にて測定することで，著者もこの方法 を朋い,この際局所麻酔にしてもし度くても殆に゙ 变りがなかつた。即ち，大の体拉注側卧位とし，

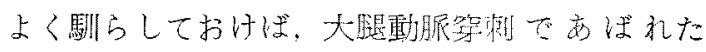

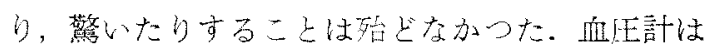
通常の水銀マノメーターを使用した。

\section{3）难動脈洞の分離潅流洼}

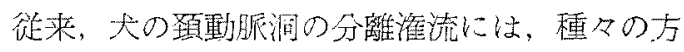
法が試みられてきた。.Moissejêff (1926) は，主

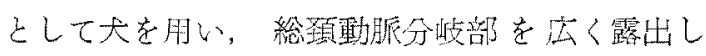

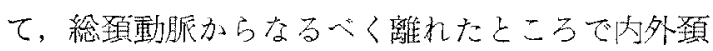


動脈を二重結倠し、頚動脈洞附近から出る分岐も

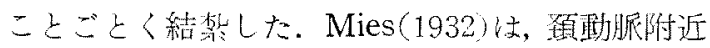

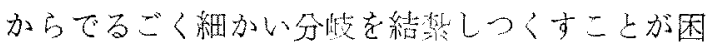

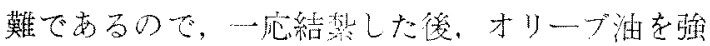
圧のもとに注入して細い勗管を閉錤した. Hering

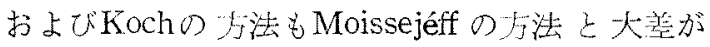

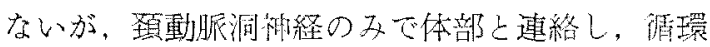

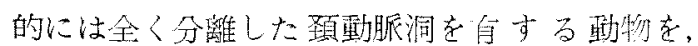
carotid sinus preparatと呼んだ. 又Heymans

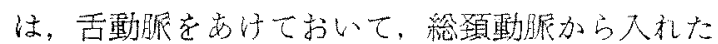

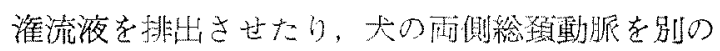
大の雨側総䅡動脈七結び、两側外頊動脈をての別 の大の外頊静脈一流すをいうち法で漼流を行なつ たり，更にはblind-sac preparationと称して，潪 流ではなく、頝動脈洞を含む盲管として両側総頚

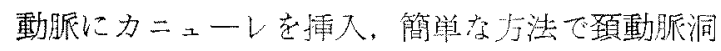

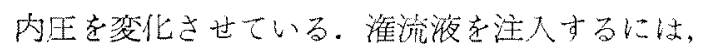
静水力学的のみならず, ポンブを用い, 浇流压に いるいろの程庭の拍動を与えることもでる。

著者はKezdiら5)の方法にならい，一側頚動脄 洞部を刨除し，他側の忩䅡動脈にカニューレを挿 入し，Fig. 1に示古ごとき潅流装置を用いて，难 動脈洞内压を全身血压とは別個に変えうるように した，分離頝動脈洞のスケッチ学Fig. 2に示す。

即ち，上甲状腺動脈分岐部より下で総頚動脈を 結禁し，頚動脈洞含む盲管々なるように，比輘的

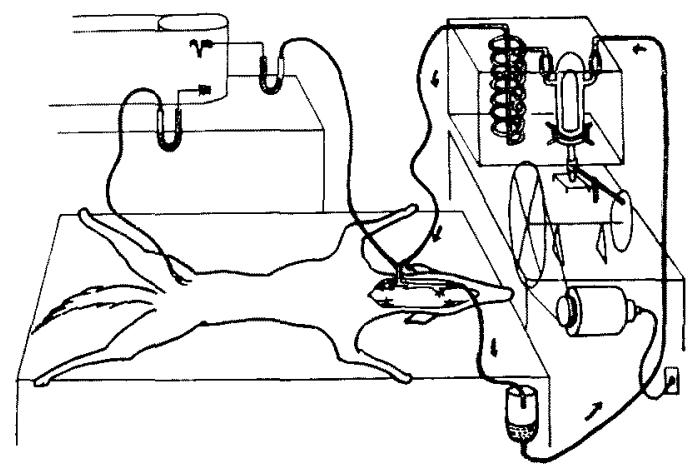

Fig. 1. Apparatus for the isolated perfusion of carotid artery.
大なる動脈よりはじめて小なる動脈もすべて結警

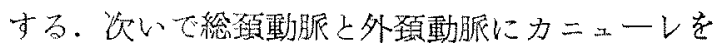

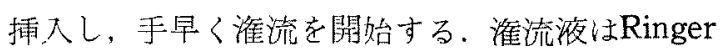

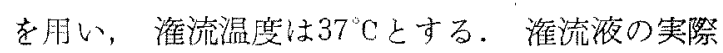
の温废が $38^{\circ} \mathrm{C}$ にるを，压受容体の感受性が低下 するという報告がある。文図でみるごとき潅流 装置によりpulsatileな圧がかかることになる。途 中，回路汢一部開放性のため，特に酸素供給恃行 なわなかつた。麻䤃はpentobarbital 30mg/kg で施 行し, 人工呼吸器を使用卞る。頝動脤洞内代は, 総䅡動脈一插入したカニューレの㨁前部より, 又 全身血代は一側の大腿勤脈より，水銀マノメータ 一にてキモグラフの煤紙上八，贡注ink-writing 法にて記録した。

4）搷動脈洞の交感神経性関与を文子実験法

まず一側の頝部交感种経を切断する。下頝部に て長さ $2 \sim 3 \mathrm{~cm}$ 程の小皮切を行ない, vagosympathetic trunkの检策にて, 迷走神経は傷つけるこ となく，比較的容易に裂感神経のみを切断するこ とができる。この神経の过回経路の存在, 走行の

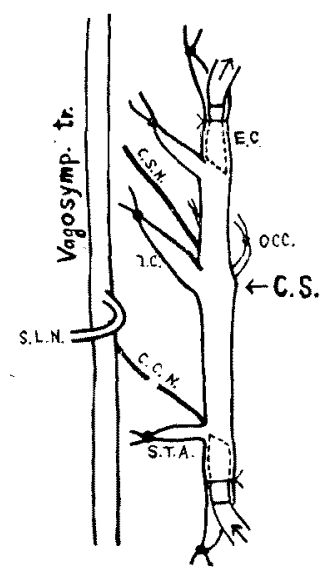

C.S. = carotid sinus: E.C. =external carotid I.C. = internal carotid:OCC. =occipital artery S.T.A. =superior thyroid artery. C.S.N=carotid sinus nerve: C.C.N. = common carotid nerve: S.L.N. = superior Iaryngeal nerve

Fig. 2. Sketch of the isolated corotid sinus. 
個体差等があるわけであるが，著者は上記の灰法 で，一回にて殆じ成功した。 denervationの成果 は，同側のHorner症候群，特に瞬膜の施緩で証 明される。汃くて、㸚部交感神経切断後 2 週間 をへて, denervationによるsensitizationの発生 したと思われる時に, pentobarbitalの麻酔下に頝 部正中切開にて, 両側票動脈洞部を露出する.人 工呼吸器を便用し，副突感神経の影響を除く意味 で，両側送走神経を切断する，全身血圧は一側大 退動脈より, 水銀マノメーターを介して煤紙上に 記録を開始しておく。艺こで, $5 \sim 10$ ronoradrenalineをまず頝部穴感神経切断側の頝動脈洞部外 膜下に注入し，全身血圧の下降々頝動脈洞閉鎖义 射抑制とを観察し，同様のこ々を反対側にも行な つて, その反応の相違から攧動脈洞の交感神経性 関与の程度を知る。

\section{実験成續}

1）碩動脈洞閉鎖反射について

1865 年Czermakがvagusdruck-versuchを乙な えこれが後にWinterbergやHeringによつて， carotissinusdruck-versuch と改められ, 臨床検
查に導入されて以来，預動脈洞反射の存在は広 く知られている. Hering ${ }^{6}$ はは顏動脈洞そのものを 加圧し, 心拍数の減りと血圧下降をみて, これを 第一点刺激といつた。これに対し，総䅡動脈を加 圧し，内腔を関鎖すれば頝動脈洞内压は下がり， 圧受容体一の刺激が減る故, 逆に血圧の上昇と心 拍数の增加をみる。これを第二点刺激と呼んだ。 実験的に総頝動脈を閉鎖すれば，血圧は上舁し心 拍数は增加する。そこで閉鎖を急にはすすする，総 頝動脈血は一時に洞内心流れ込み，洞壁の圧受容 体を刺激する、それ故，血圧は以前のレペルより もかえつて一時低下し，しかるのち以前の值にも ぞる。心拍数の变化も同様であり,この一過性な がらみられる血圧の低下，心拍数の減少はHering の第一点刺激に相当すると考えられる。なお， 一般に埕動脈洞内压の変化に対する全身血圧の在 応の現われには，数秒のおくれ加認められる．頊 動腺洞神経を除去すれば，頚動脈洞の压迫による 巨射も，頝動脈洞閉鎖反射も殆どみられない。従 つて, 頚動脈洞閉鎖反射をみることによつて，圧 受容体の働きをある程度まで知ることができる。
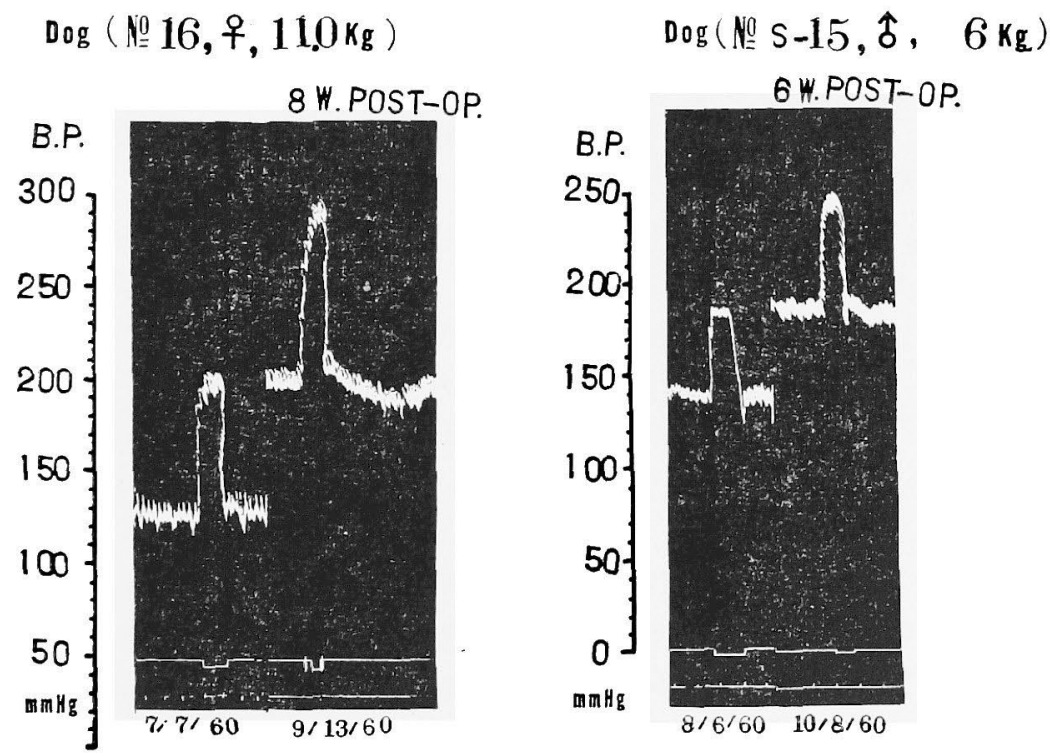

Fig. 3. Carotid occulsion reflex in course of experimental renal hypertension in dogs. 


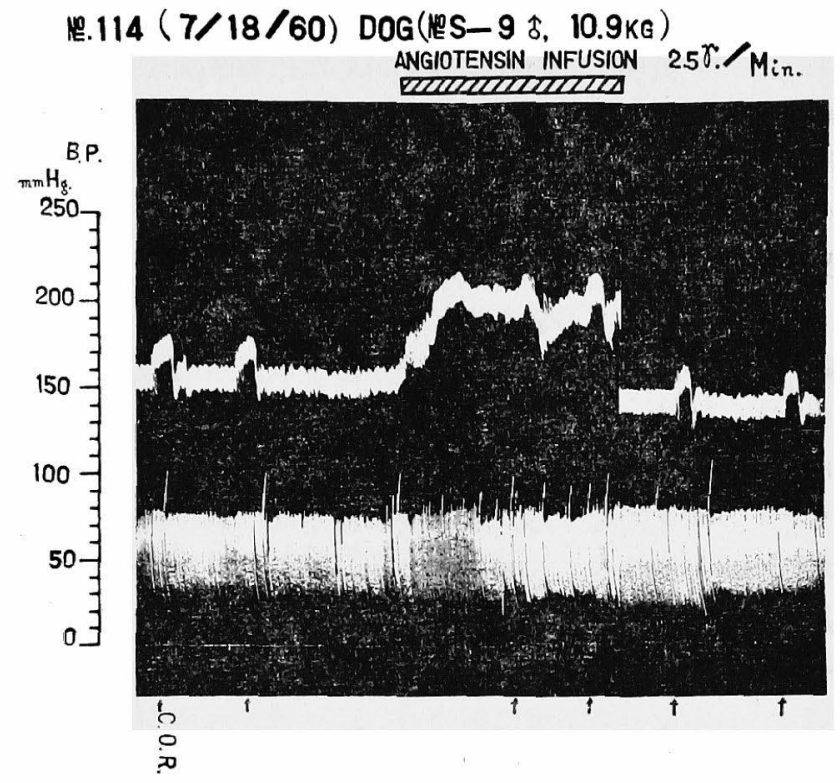

Fig. 4. The carotid occulsion reflexes in normotensive and acute hypertensive state.
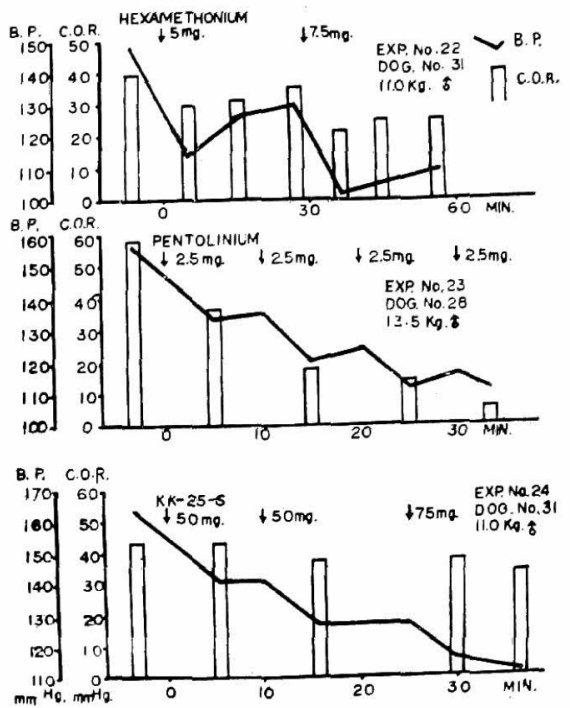

Fig. 5. Influence of ganglion blocking agents on blood pressure and carotid occulsion reflex.
因に，一側閉鎖反射に比して両側閉鎖反射で は，倍以上の反応を示すのは当然である。

a）慢性腎性高血圧犬の頝動脈洞閉鎖反射

頝動脈洞閉鎖反射は, 慢性高血圧の発生に伴な つて增大することは既に認められている7)，著者 は，高血圧手術後 6 週の高血圧犬において，既に この反射の增大をみている (Fig. 3). 即方, 術前 の全身血圧が $140 \mathrm{mmHg}$, 両側同時頝動脈洞閉鎖 反射が $45 \mathrm{mmHg}$ であつたものが，術後 6 週間で 全身血压は $185 \mathrm{mmHg}$ と上昇，開鎖反射は $65 \mathrm{~mm}$ $\mathrm{Hg}$ と増大している。同じく临後 8 週間の高血圧 犬では，術前の全身血圧が $130 \mathrm{mmHg}$ ，閉鎖反射 が70mmHgであつたのが，全身血圧 $200 \mathrm{mmHg}$ と上昇するに伴ない，閉鎖反射も $100 \mathrm{mmHg}$ と増 大している.なおこの際に注意すべきことは，閉 鎖反射の大きさは個々の大によつてかなり異なる ことであり，従つて閉鎖反射の増大を論じる場合 には、同一大にて観察せね将ならないこである。

反射の増体にかんする，この実験の段階では， 高血圧犬においては，閉鎖による頝動脈洞内圧の 変化がより大であるためと，預動脈洞の感受性の
增大と，二つの可能性が考えられよう。

しかしながら，一過性に全身血压を上昇せしめ た際にも，この反射の增大はみられるであうう か. angiotensinを一是速度( $2.5 \% / \mathrm{min})$ で静注す ることによつて，血圧レベルを一過性に同程度ま で，即ち $50 \mathrm{mmHg}$ 上昇せしめた際には，Fig. 4 にみる如く，むしろ反射の抑制傾问を示してい る。

従つて, 慢性高血圧の発生に伴なう反射の増大 は，単に血王レベルが上昇したことのみによるも のではないことが示される。

b）頝動脈洞閉鎖反射々節遮断剂の影響

腎性高血汇において，交感神経の興舊増加怔あ るかという問題は，一般的に直接的な証拠に泛し く，否定的な意見が多いようである。交感神経緊 張増加の問題と関連して, 節遮断剤に対する降圧 反応を, 高血生の発生前後について比較検討した 著者ら ${ }^{8)}$ の成績でも, pentolinium, hexamethonium, TEA，KK-25-S等の節遮断剂を静脈内投 与した際の降圧反応は，必ずしも高血圧状態にて 反応增強を示すとは限らなかつた。しかしこの 

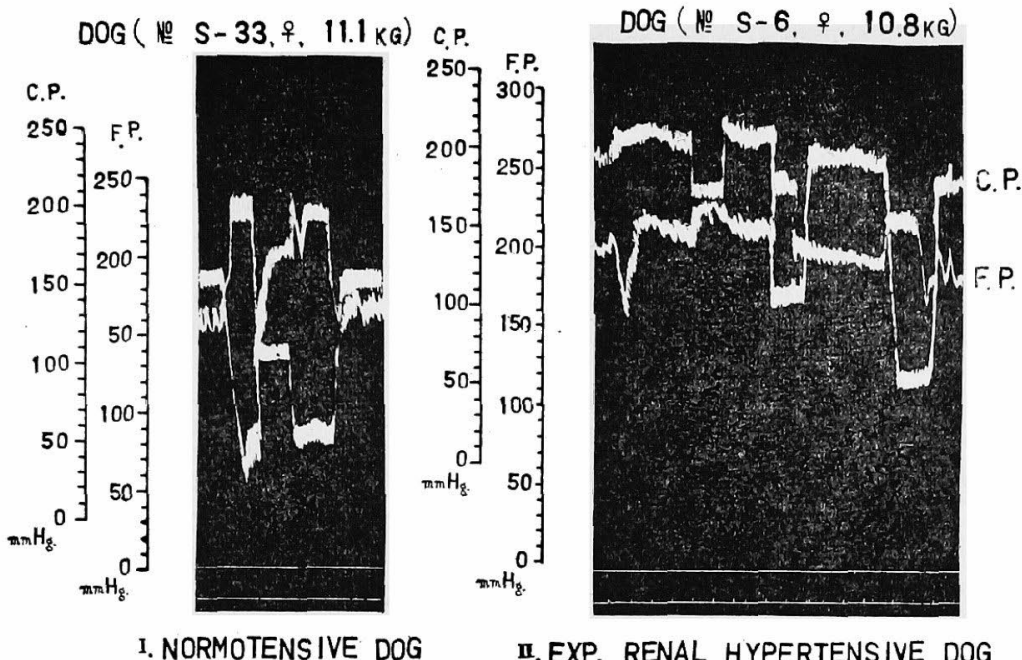

Fig. 6. Relationship between mean carotid sinus pressure and mean femoral artery pressure in normotensive and hypertensive dogs.

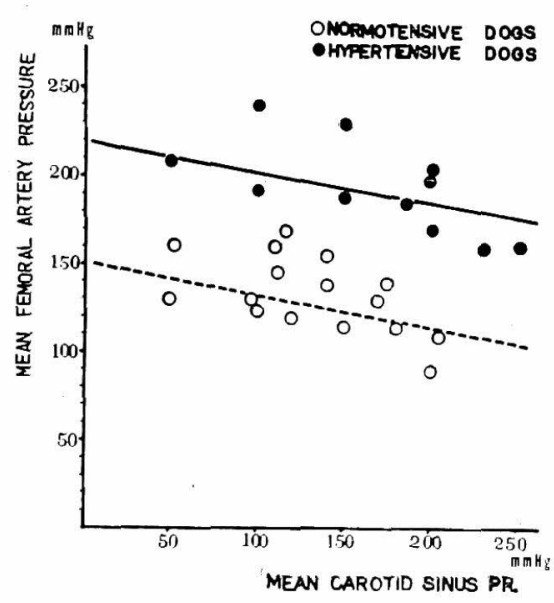

Fig. 7. Relationship between mean carotid sinus pressure and mean femoral artery pressure in normotensive and experimental renal hypertensive dogs.

際, 高血圧作成後の期間の問題, 遮断剤の量の問 題等も多少影響があるようにも思われた。

そこで,このように節遮断剂を静脈内投与して 降圧反庆をおこさせた際に, 両側頝動脈洞閉鎖反 射との関係を観察してみると，一般に降圧反応と 㪄動脈洞閉鎖反射抑制とは，平行関係にないこと
が示される (Fig. 5). 即ちこれは慢性腎性高血圧 犬での例であるが，降圧効果の割には反射の抑 制が著しくはない。しかし， pentoliniumに対す る降圧反応と反射抑制とは，かなり平行関係をも つていると思われる如く, 節遮断剤の種類や使用 量者影響するように思われる。いずれにしても， 交感神経性の遠心路のより完全な遮断には, 充分 量の遮断剤が必要のように思われる.なお,以上の 自律神跬遮断郕と異なり，末梢の交換神経遮断剤 として, 近時臨床的に使用されている, bretylium やguanethidineでは, 頊動脈洞閉鎖反射を顕著に 抑制するという報告のあるのは興味深い.しかし これにも異論はあり, Booker ら ${ }^{9}$ は, 両側頝動脈洞 閉鎖反射洔の血压上昇とcathecholamine release とは密接な相関をもつことを示し， reserpineは 両者其抑制するがP-286 (alkyl ureaの一種, cathecholamineの分泌を抑えるとされている)で は不充分であり， bretyliumでは抑制しないとし ている.

2）頝動脈洞分離潅流による実験

a）頝動脈洞内圧と全身血圧との関係

まず，䈯動脈内压を変化させた時の全身血圧の 
変動を観察した．正常血圧犬と慢性腎性高血圧犬 について，既述の方法にて頝勘脈洞を分離㴶流 し, 頝動脈内圧を適宜に变化せしめ, 同時に全身 血圧の変勤を煤紙上に記録した。その例を示せば Fig. 6 の如くである.

かくしてえられた頊動脈内压と，その時の全身 血压の值を一点として, 横軸に頝動脈内王, 緃軸 に全身血圧をとつたグラフ上に記入すると，Fig.
7 となり, 高血圧群では正常血压群を縱軸にかん して上方へ平行稆動させた如くに表現される．即 ち, 頚動脈内压に対する全身血圧の関係は，高血 圧群と正常血性群とで, ほほ平行関係を示し, 従 つて一定の頝動脈内圧の変化に対する全身血圧の 変化の割合は等しい，いいかえれば，頝動脈洞の 感度自体には, 正常血圧大と慢性腎性高血圧大と で差異がないといえる。
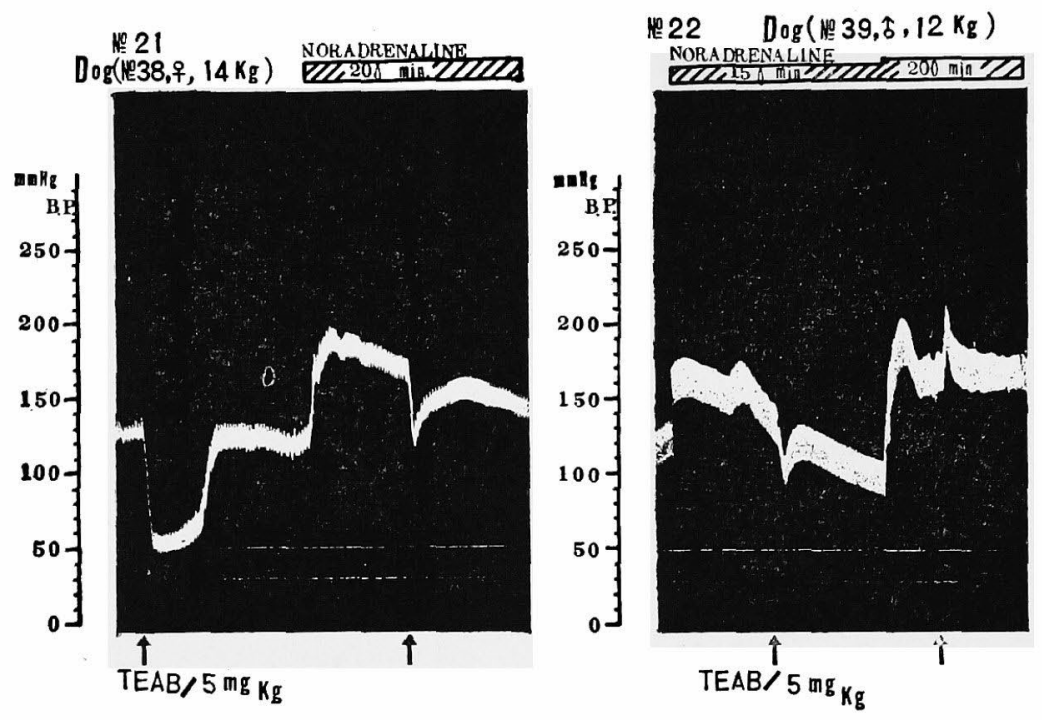

Fig. 8. TEAB response before and after noradrenaline infusion.

RE 15 ( $9 / 1 / 60)$ DOG (NO30,8,14KG) NORMOTENSIVE DOG

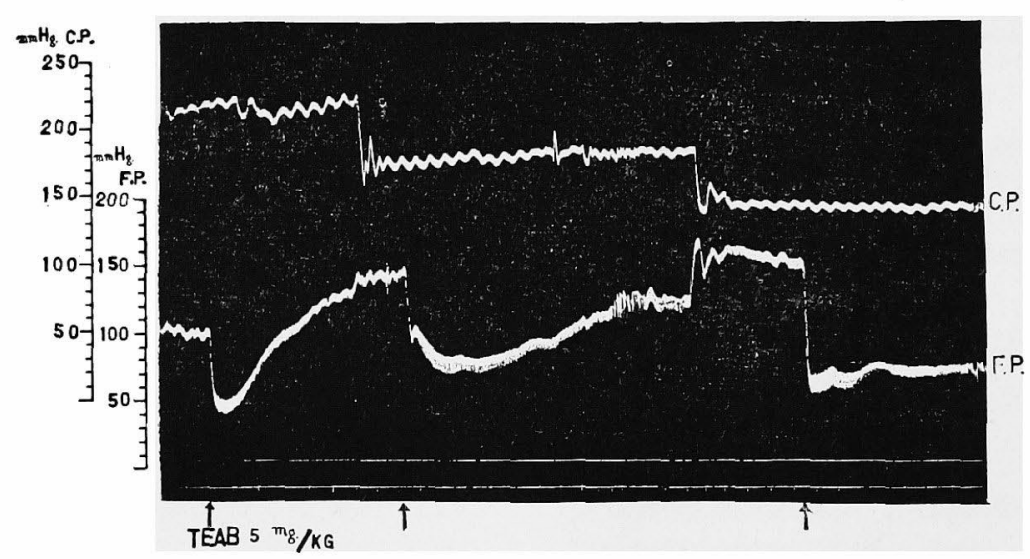

Fig. 9. TEAB response at different intrasinusal pressure levels. 
b）頝動脈洞内圧と T E A の降王効果

頊動脈洞内圧の変動により, その反射遠心路で ある交感神経興奮の程度が变化するわけである が，この交感神経を通る興奮の程度をはかる手段 として，充分な量の節遮断剂を用いた際に示され る降圧の程度からこれを比較することができ る、例えば，正常血圧犬で血王レベルを一過性に 上昇せしめると, 圧受容体を介しての遠心路の交 感神経興奮は減少し, 従つて節遮断剤によつて抑 制される部分は少なくなり，節僬断剂に対する降 圧反応は減少することになる。

即ち，著者は正常血圧犬でnoradrenalineを15 〜20 $/ \mathrm{min}$ で点滴静注することにより，血圧レベ ルを一過性に上昇せしめ, 節遮断剂としてはT E ABを $5 \mathrm{mg} / \mathrm{kg}$ 静注することにより，この反応を 観察した (Fig. 8). 図に示されるごとく，正常時 のTEAに対する降圧反応にくらべ，一過性血圧 上昇時の T E A に対する降圧反応は減少し, 遂に は逆に昇圧反応を示す場合すらみられる。この昇 圧反応は, 副交感神経遮断作用が更に優位となる
に至るためと考えられる。

以上と同じ理由により，頝動脈洞を分離潅流し た犬では，頚動脈内压を下降せしめれば，TEA に対する全身血圧の反沁は大とる (Fig. 9).

そこで，頝動脈洞を介しての反射遠心路たる交 感神経興鹪の程度を，正常血圧大と慢性腎性高血 压大とで比較検討する目的で，同様の実験を両者 について施行した. 即ち, 預動脈内圧を変化せし めた際の，そのおのおのの斋動脈内圧における $\mathrm{EA}$ Aによる降圧の程度をみると，両者共同様の傾 向を示す (Fig. 10 と11).

この両者の変化を一つの図に表わし，横軸に㸚 動脈洞内压を，縱軸に全身血圧をとつて記入す ると (Fig. 12), 次のことが示される.

即ち，第一は，TEAによる降圧後の血珐值の 間に，正常血王大と慢性高血圧犬とでほほ平行関 係が認められること、第二には，おのおのに拈い て頝動脈洞内压と全身血圧とが等しい点，即ちを の個体の本来の血压のところ（四では二重丸の 点)では，両者のTEAに対する反応の大きさが

R133( $(8 / 24 / 60)$ DOG (NoS-33.7. 11.1KG) NORMOTENSIVE DOG

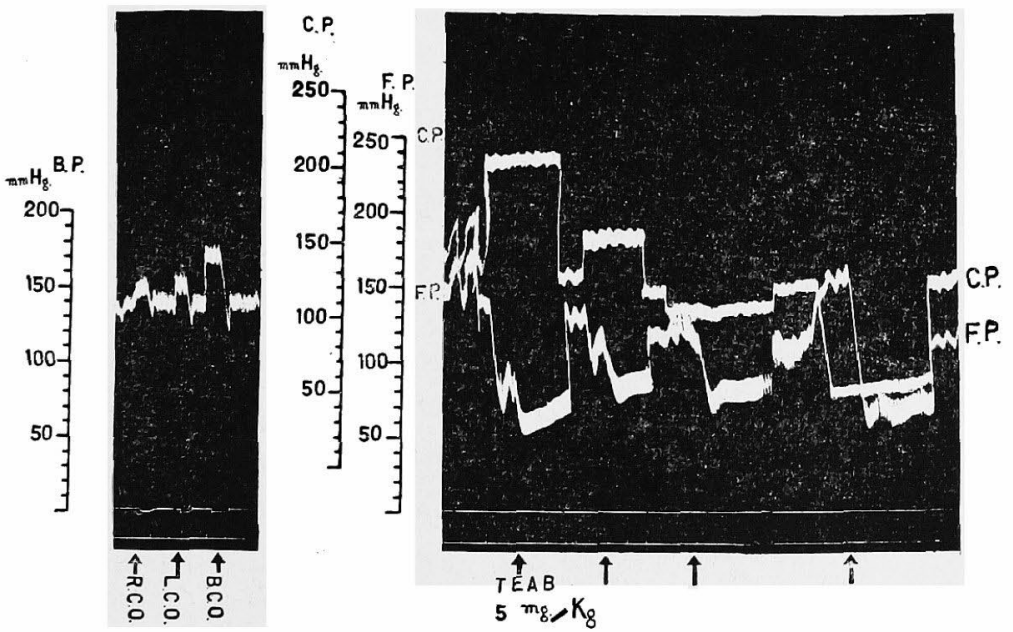

Fig. 10. TEAB response at different intrasinusal pressure levels in normotensive dogs. 


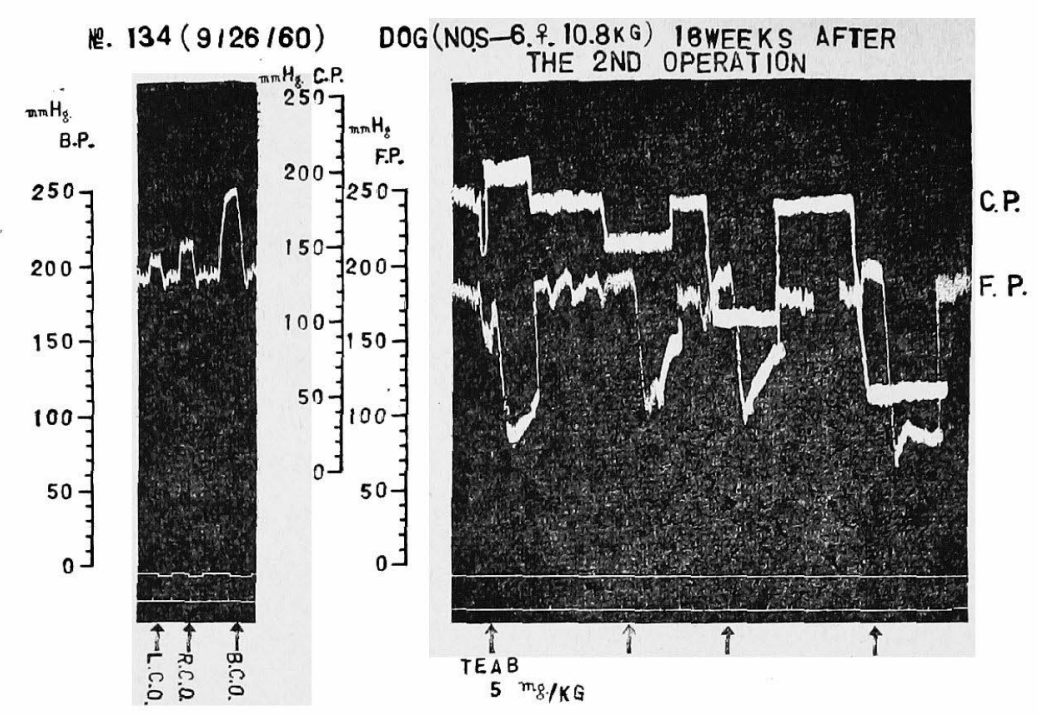

Fig. 11. TEAB response at different intrasinusal pressure levels in hypertensive dogs.

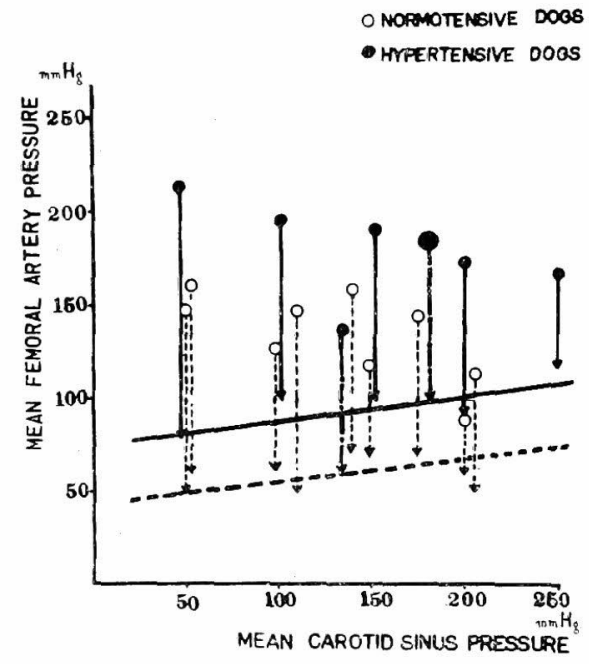

Fig. 12. TEAB response at different intrasinusal pressure levels in normotensive and hypertensive dogs.

ほほ等しいことである。従つてこの2点からも， 圧受容体の反応そのものには，両者間に本質的な 差異がなく，慢性腎性高血圧大では，たな゙もとに なる血圧レベルが上昇したに過ぎないということ がいえる。
3）頝動脈洞の交感神経支配について

預動脈洞の交感神経支配にかんしては，先に

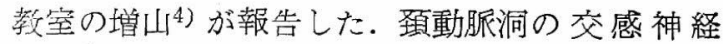
性影響についての，これまでの成績は必ずし一 定していない，即う，Palme10)は，動物実験で頝 部交感神経を電気刺激することによつて，全身血 モの下降することを示し，これは䅡動脈洞の感受 性への影響によるものと考えた。一方, Floyd Neil ${ }^{11}$ は，頝動脈分岐部一の交感神経分枝を刺激 しても，頚動脈洞の圧受容体としてのactivityに は変化を与えないことを示した，Kezdi12)は，玨 動脈洞部一ゆく交感神経枝を分離して, 電気刺激 を持続的に行ない, 全身血圧の下降々頝動脈洞舁 厄反射の減弱を観察した。增山は，大で下㸚部に て一側頝部交換神経切断後，2週間をへて，Cannon \& Rosenbluethのいうdenervation-sensitization の発生したとみられる時期に, 頝動脈洞の局 所外膜下に, 少量のnoradrenalineを注入して, え られた全身血圧の下降と，㑯動脈洞開鎖反射抑制 とを対照側と比較し，血圧下降と反射抑制とが， 交換神経切断側にてより著明にみられることよ り，頝動脈洞の交感神経性支配の関与することを 


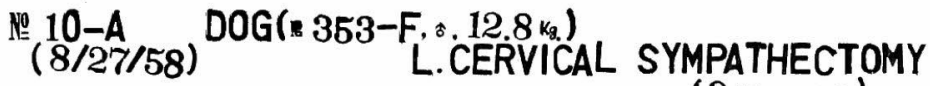 \\ $(8 / 13 / 58)$}
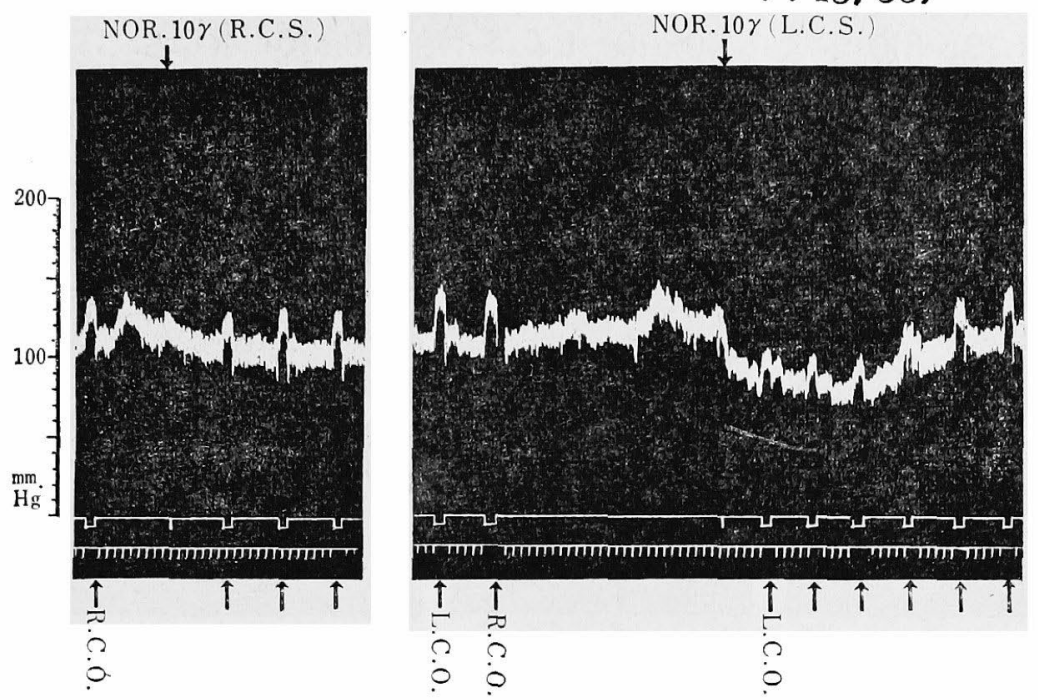

Fig. 13

示した(Fig. 13).

著者も同一の方法にて, 慢性高血圧状態での, この埧動脈洞への交感神経性関与の程度の変化 を知るため，実験を行なつた。即ち，5〜10\%の noradrenaline 㸚動脈洞部の局所外膜下に注入 した際の, 全身血圧の下降々澒動脈洞閉鎖反射の 抑制とを観察するのであるが，まず頝部交感神経 切断側で行ない, 全身血圧々頝動脈洞閉鎖反射の 回復をまつて，次いで反対側にて同様なことを行 ない, 最後に反対側の㸚動脈洞部を切除したのち, 切断側にて行なつた.この二つの反応は, 正常血 死犬では，頝部交感神経切断側にて，ともに反対 側で行なつた場合より大きく，反対側頝動脈洞部 切除後に切断側にて行なつた場合には最も顕著之 なる (Fig. 14)。一回のnoradrenaline注入による 反応は，その反応の大きさに従つて，30〜60分 にて全身血圧も晅動脈洞閉鎖反射も，もとの值に 回復する.Fig. 15は, 術後 6 週の腎性高血圧犬 にて，10チのnoradrenaline を頝部交感神経切断側 と反対側との頝動脈洞部外膜下に注入し, 更に
は反对側頝動脈洞部を切除して同様の実験を行な つたものであるが，その際の全身血圧の下降と頝 動脈洞閉鎖反射抑制とをみると，正常血圧時と量 的に㱠ど同じ反応を示している.

更に判定し易いように，横軸にnoradrenaline 注入後の時間, 縱軸に全身血圧をとつて, 正常血 压群と慢性高血圧群との全身血圧の変化をみる と, 降圧反応の大きさも時間的な経過も, 両者で 殆ど差異がないことが示される (Fig. 16). 頝動 脈洞閉鎖反射の抑制とその回復は, 全身血王の変 化とほほ平行して観察され、ここでも両者に差異 が認められない。即ち，頚動脈洞の交感神経性影 響にかんしても，慢性高血圧状態にて，交感神経 が正常血圧時と同様の関与をしていることが示さ れた。

4.) 神経性高血玉の作成にかんして

四つの調圧神経, 即ち左右の頝動脈洞神経と大 動脈神経を切除すれば，動物で実験的に高.血圧 症を作ることができる。 Kremerらは家鬼で行な い, Heymansは大でこれを行なつた。これはいわ 
N0. $17 .(9 / 9 / 60)$ DOG (N0.34. \$.9.5 KG)

BEFORE THE SECTION OF L.C.S.

AFTER THE SECTION OF L.C.S NOR. 10r. R.C.S<smiles>[R10]NC(=O)ON</smiles>
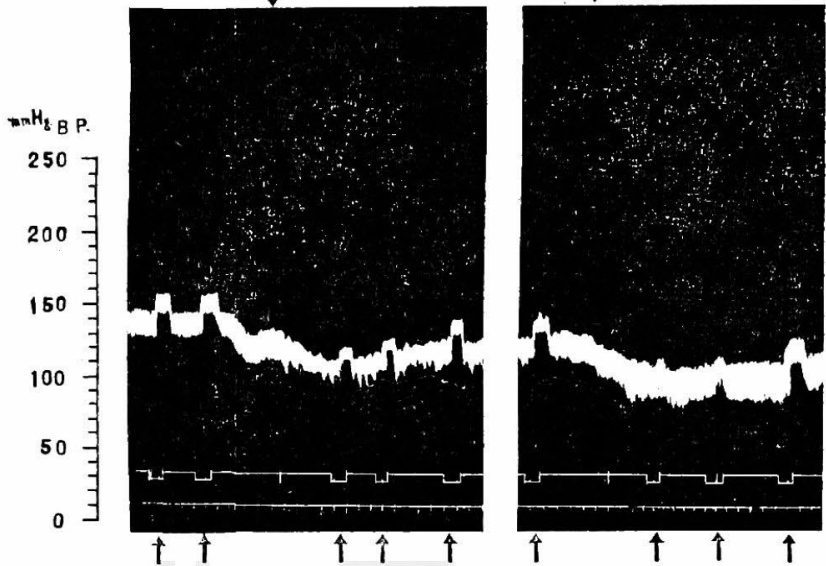
NOR.10r. R.C.S.

$\downarrow$

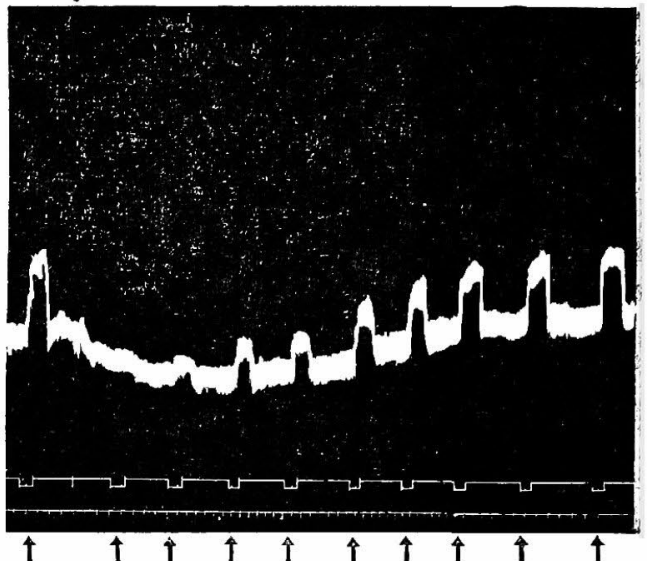

்ֻ

ְִ

గ̊

Fig. 14. The influence of the sympathetic innervation on carotid sinus activity (normal control).

는 $18(9 / 13 / 60)$ DOG (№ $16,9.11 .0 \mathrm{KG}$ ) (8/30/60 R. CERVICAL SYMPATHECTOMY) 6 WEEKS POST-OP.

BEFORE THE SECTION OF L.C.S. NOR. 10r. L.C.S. NOR. 10 r. R.C.S.

Fig. 15. The influence of the sympathetic innervation on carotid sinus activity in hypertensive dogs.
AFTER THE SECTION OF L.C.S. NOR. 10 r. R.C.S. 
Before the Section of C.S. on the Other Side

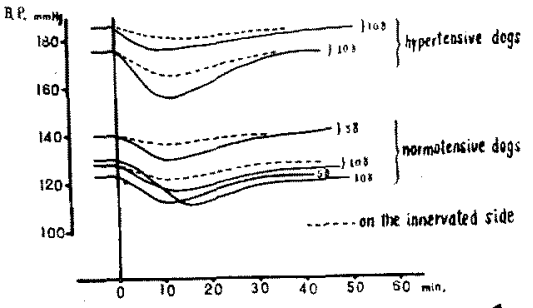

Aftea the Section of C.S. on the Other Side

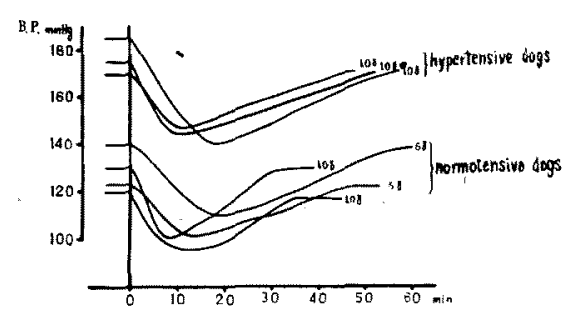

Fig. 16. Blood pressure responses to noradrenaline applied subadventitially into the carotid sinus area on the denervated side before and after the section of C.S. on the other side.

ゆる神経性高血圧であつて，細動脈変化の少ない ことや心肥大の少ないことが，実験的腎性高血压 と異なるといわれていた。この高血圧では，興鹪 している時は血圧が高いレペルにあるが，眠つた り静かにしている時は血生が正常に近いというよ
うに，不安定であるのが特徴である。しかし長時 日の後には，腎の細動脈にも硬化が起こるといわ 孔る。

榴沢と斎藤 ${ }^{13)}$ は，神経性高血圧大では $2 \sim 6$ 週 で血告レベルがもとに房り，14週まで高血圧が持 続したのは1例のみであつたと報告している。

Fig. 17, 18 は著者の行なつた神経性高血圧作成。 の過程を示したものである。

術中，大動脈神経の切断では殆ど血圧の変化は みられず，一側頝動脈洞神経の切断でや〉上昇 し，残れる頝動脈洞神経の切断で顕著に上昇して いる．Fig. 18例で郝後ただちに血圧の下降傾向 を示しているのは，手術がや>長びいたのと陎酪 の影響がかなりでているためと思われる。という のは、この例では手術前麻醉下の血圧が $140 \mathrm{~mm}$ $\mathrm{Hg}$ ，手術終了跱の血正が $135 \mathrm{mmHg}$ である゙， 術後最高租王が $180 \mathrm{mmHg}$ に啈し，術後 6 週目の 軽度麻酔下の血压がなお $150 \mathrm{mmHg}$ であつたか らである。しかし早晩，血圧がもとのレベルに房 るのは，切除した神経の再生，大動脈神経迁回経 路の存在, その他の部拉に存在する生受容体の作 用によるのであろう。なお，著者の経験では, 神経 性高血圧大では秝酔に対して非常に弱いと認めら れ，Fig. 17例では，術後経過篗察中に, pentobarbitalの通常の麻酔量（30mg $/ \mathrm{kg}$ ) の $2 / 3$ 量で死亡 Lた.

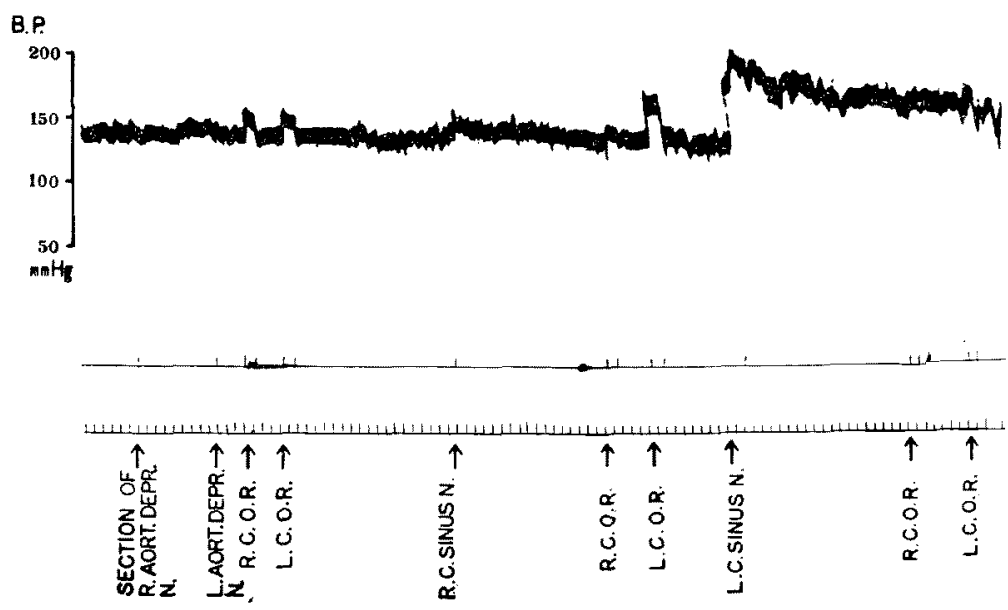

Fig. 17. Blood pressure changes by the section of both carotid sinus nerves and aortic depressor nerves in a dog. 


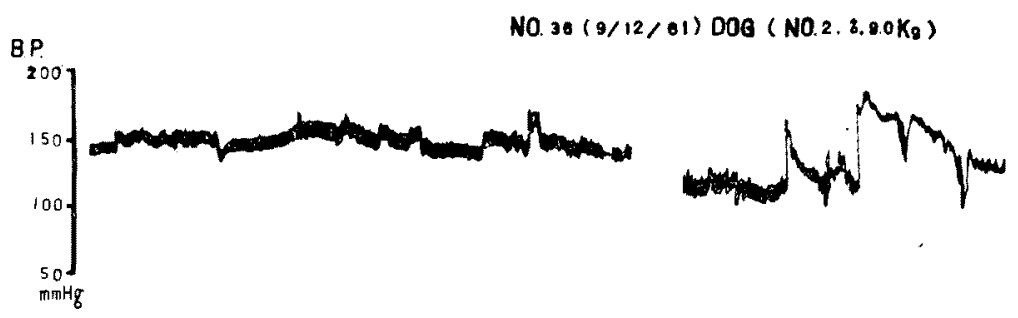

\begin{tabular}{|c|c|c|c|c|c|}
\hline 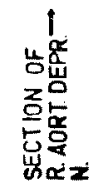 & 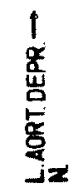 & $\begin{array}{ll}1 & 1 \\
\alpha & \alpha \\
0 & 0 \\
0 & 0 \\
0 & 0 \\
\alpha & 0\end{array}$ & 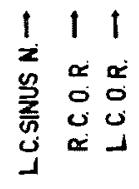 & 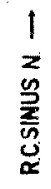 & $\begin{array}{l}1 \\
\alpha \\
0 \\
0 \\
0 \\
\alpha\end{array}$ \\
\hline
\end{tabular}

Fig. 18. Blood pressure changes by the section of both carotid sinus nerves and aortic depressor nerves in a dog.

\section{考案}

まず，腎性高血圧の神経性調節にかんして考察 を加えたい，renin-angiotensinを中心とした体液 性機構は, Goldblattの実験的腎性高血压でも，又 ヒトの腎性高血圧症でも，初期のある限られた期 間には主役を演じているが，慢性高血王で注次第 に他の因子のしめる役割が璮してくると，従来考

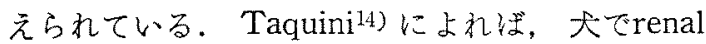
ischemia後，腎のrenin含量注60分以内でpeakに 達し，高血生が進行するにつれて正常值に減少す るという。一方，数力月続いたGoldblatt高血王が 㷋簎をといても，もとのレベルに送らないという 事実がある.家鬼や大では,一側の腎動脈を陊管し

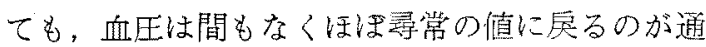

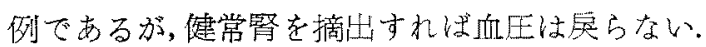
renin-angiotensin系に加んして蚗，今日去の化学 的及び生物学的研究がすす及，特にその生化学的 な面での進歩注顕著であるが，なおその溳定法に は幾つかの問題点が残されており，二れが高血王 におけるR-A系の役彗についての難点となつてい る。一方R-A系に対してこれを破壞ないし不活性 化卞る醉素の存在や抗高血庄物質の存在が考えら れており，徒つて現在の段階では，腎の renin 含
量や血中の angiotensin 量の消長から，すぐ慢性 高血圧期の昇王機構を腎外性の要因にもつてくる ことはできない，しかし，現在一般的には，実験 的腎性高血玨の急性期には，主として体液性機構 が，そして後の慢性期の血圧の維持には，神経性 機構がか疗り関与すると考えられている。

それでは，慢性腎性高血圧については，交換神経 緊張增加があるかという点にては，犬で尿中力テ コールアミンの壇量は特《認められず8)，又著者 らの成績でも述べたように，節遮断剂に対する区 応についても常に交感神経緊張増加があるとは認 めがたい，更に，一般的に慢性高血圧患者の厡 中カテコールアミン量は，有意に加つ定常的に堷 してはいないし，流血中のカテコールアミン量当 増加していないといわれる。一方，Page ${ }^{15)}$ 長期間たつたGoldblatt動物の脈管系が，脈管收 縮物質に対して詨照より笅感になっていることを みた。この点については最近も検討が続けられ， 著者ら ${ }^{16)}$ 为報告した。

これらのことは，实騒的腎性高血圧の発生には R-A采加体液性因子の面からとりあげられている が，高血圧の維持には，神経性特に圧受容体の関 与，あるい梳-A系以外の体液性变化や，血管の 
感受性增加等が意味をもつことを示唆している。 そこで，実験的腎性高血压における神経性因子 については，特にHeymansらを中心をする压受 容体にかんする研究以来，圧受容体の関与につい て近年検討汃続けられている。慢性腎性高血王に て在受容体の反范の变化が起こつていないかるい う問題にかんし，塚田 ${ }^{17}$ は，大の頝勒脈洞標本に ついて血圧特性曲楾を作り，亚動脈洞反射が正常 と同じか, 㕛はそれ以上で亦り，調圧神経は尋常と おりあるいはそれ以上に锶いているとした，Heymans ${ }^{18)}$ は，大の頊動脈洞部局所外膜下にadrena line, noradrenaline等を注入することにより，動 眽壁のtensionが堌加して全身血王の下降するこ とを述へ，文Matton ${ }^{19}$ )は，全く同樣のことを腎性 高血厈犬について行ない，血玨の下降が正常血 圧大と同様であることを観察した．更には，NcCubbin, Green \& Pageは, electroneurogram いて考察を行ない, 各血圧レベルでのimpulse 記 録せしめ，慢性筲性高血圧犬の頚動脈洞神経より のFiringは，正常血压犬のそれと同积度で增加し ていないことをみ，高血圧の経過において，王受 容体が“reset”され，玨受容体の機能吕高血任に 対して減圧的に法衝かす，むしろ維持する倾向を もつという見解を発表するに及んで，腎性高血圧 における压受容体のresettingが，一般的に諗好 れるところとなつている。

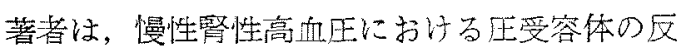
応を適確に知るため, 頝動脈洞分離潅流による寒 験で考祭をなし，又特に動脈洞の交感神経性支 配の問題を中心に選九で検討したのも，腎性高血 压における頊動脈洞の，このいかゆるresettingの 問題を解明せんとするにあつた。即ち，まず，腎 性高血圧で圧受容体の感受性の変化があるか否か を, 頝動脈洞内压の変化に対する全身血生の変動 という、はつきりした形でとらえ，頝動秡洞内压 の一定の变化に対する全身直圧の変動の割合は,

正常血圧犬と高血王大とで差がないことを確かわ た。更には，頝動脈内正とそのおのおのの内圧レ ベルにけるTEAによる降圧の程度を，正常血
压大と腎性高血圧大とで比較し，TEAによる降 圧後の血任值の間に, 両者間にほほ平行関係が認 められ，かつ頝動脈内压之全身血压とが等しい点 では，TEAによる降压区㐫が等しいことを証 めた。これらのことは王受容体の感度々のものに は，正常血珐大と差暴がなく，ただもとになる血 殴レベルが上翟したに過ぎいことを示してい る。

なぜ，士昇した血压レベルに対して在受容体が 反応しないかという問題は，加〉る纴受容体の resettingによつて說明されるとしても，このresettingの成立機序は，未だ不詳である. Heymans はこれを，動脈壁tensionの異常孛低下による，压 受容体の被刺激性の減退によるとした。しかし， 圧受容体を含む動脈壁の変化の原因が，留性高血 圧の経過に生じた体液性因子によるのか，洞内王 の上昇による镸期の壁伸展による機械的因子であ るのか等，不明である。

著者は、この点について, 攧動脈洞への交感神 経支配の影響が巽なるためではないかと考え，検 討したが，その影響の程度は正常血生㭙上同様で あつて, 結果的にはresettingの一面を意味づける ことになつた。

Tobian \& Redleaf (1958) が示した，電解質 の变化及び water lodgingは，圧受容体壁のdistension 部說明する方导しいない. Hilgenberg

（1959）は，とトの高血压で，主受容体終末の

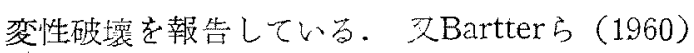
は, 上甲状腺動脈分岐部に存在する圧受容体は, aldosterone㕍生に影響をもつことを示睖したが， もし民受容体がsympathetic outflowのみならず, aldosterone應生を調節するとするなら, aldosterone 厓受容体のresettingに関与する可能性 も老えられる。

しかし，この方面の問題で注目すべきものに， Kezdi20)の報告がある。彼注犬で総頙動脈を雨側 とも_上状腺動脈より頭部で狹窄し，洞内任方全 身血压以下に存るようにして㧈いて，腎性高血压 犬を作成した，高血压は充分成立されたが，腎趿 
脈神経からのFiringを記録してみると，減王処䈯 した洞々全身话環をつなげば增加し，全身側の血 压レベル以下でも，更には50mmHg位でも Firing が存在した。即ち，全身の高血圧成立にも拘ら ず, 压受容体のresettingは成立しないことになる。 それ故彼は，もし体液性因子队笔解賢の変化が resettingの原因になるなら，預動脈の狄管にか かわりなく洞に影響するはずであると仙へ，頊動 脈洞のresettingは高血压症そのものによると考え た。即ち, 高舟压のもとに動脈の伸展名強く続き, 受答体のある動脈壁に变化を与え, その結果, 洞 の被刺激性は漍少してhigher setないし resetting が促されるとした。てうたとすれば，高血压によ る二次的の影暗が，このresettingの現像の中に含 まれることになる。

\section{結 論}

実験的腎性高血圧における神経性因子につい て, 圧受容体の関与の問題を検討するため, 正常 血圧犬と寒験的緊性高血圧犬とについて，以下の ように実験し，考察を加えた。

1）頊勳脈洞閉鎖反射の増大は，術後 6 週の腎 性高血圧大にて既に認められるが, angiotensin点 滴静注による一過性高血圧では, 反射の抑制があ り, この反射の増大は単なる血圧レベルの上景の みによるものではない。

2）頊動脈洞分離潅流による実験にて, 嵮動脈

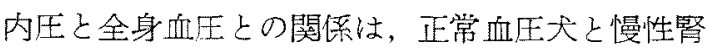
性高血圧犬とで, ほほ平行関係を示す。即ち, 攧 動脈内压の一定の变化に対する全身血王の变勳の 割合注等しい。

3）顼動胍洞分離潅流による奏験にて, 难趿脈

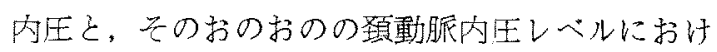
るTEAによる降圧の程度を, 正常血圧大と慢性 腎性高血圧大とで比較すると，両者とも同様の傾 向を示す。この場合のTEAによる降压後の血圧 值の間にも，两者間にほほ平行関係が諗められ， かつ頊動脈内戍と全身血圧の等しい点では，TE Aに対する反応の大きさは等しい。

4）頊動脈洞の交感神経性支配にかんしては, 一側頝部交感神経切断後 2 週間をへて, sensiti- zatioの発生したと思われる時期に，难動服洞部 局所外膜下に少量のnoradrenalineを注入してえら れた，全身血王の下降之頝動脈洞閉鎖反射抑制之 が，対沿側より交感神経切断側にて著明にみられ ることで示され，これを正常血圧大と慢性腎性高 血王大とて圷較し，䅡動脈洞の交感神経性影響に かんしても，雨者で同様に関与していることが示 される。

以上，2)3)4)上り，慢性算性高血比犬では，压 受容体の感度ないし反応そのものには，正常血在 大と本質的差異がなく，た詻もとになる血任レべ ルが上昇したにすぎないこと，及げ頝黝脈洞に対 する笑感神経性影響も同椂であることが結論され る.

\section{文献}

1) Goldblatt, H., Linch, J., Hanzel, R.F. \& Summerville, W.W.: J. exp. Med., $59: 347,1934$, -2) Page, I.H.: I.A.M.A., 113:2045, 1939. -3) Heymans, C. \& Neil, E.: Reflexogenic Areas of the Cardiovascular System. Little, Bro. wn \& Co., Boston, 1958. -4) Masuyama, Y.: Jap. Heart J., 1: 169, 1960. -5) Kezdi, P. \& Wennemark, J.R.: Circulation., $17: 785,1958$. -6) Hering, H.E.: Verh. Dtsch. Ges. Inn. Med., 35:93, 1923. -7) McCubbin, J. W., Green, J.H. \& Page, I.H.: Circulat. Res., 4 : $205 ， 1956 ，$-8）增山善明, 山中羊吾, 大野由紀 子, 井上昇, 杉山規矩雄、村田正, 鈴木宏: 日本 䠦术, $19(5)$ : 981, 1961. 一9) Booker, W.M., Fisher, E., Coffey, W. \& Linares, R.: Arch. int. Pharmacodyn., $139: 159,1962 .-10)$ Palme, F.: Exp. Med. Surgery, $9: 404,1951$. 11) Floyd, W.F. \& Neil, E.: Arch. int. Pharmacodyn., 91 : 230, 1952, -12) Kezdi, P.: Circulat. Res., $2: 367,1954$. - -13) 桜沢富士堆, 率 藤十六：日内会誌, $30: 249,1942$ 。 - 14) Taquini, A.C., Taquini, A.C. Jr. \& Blaquier, P.: Circulati. $17: 672$, 1958, - -15) Page, I.H.: High Blood Pressure, London, 1955. - -16) 增山善明, 佐藤利平, 山中羊吾, 大野由紀子, 杉山䂓矩雄, 村 田正，鈴木宏：最新医学，18(6) : 1254, 1963. -17) 塚田英雄：日大医学雑誌。12（3）：191, 1953. - 18) Heymans, C. \& Van Den Heuvel, G.; Arch. int. Pharmacodyn., $83: 520,1950$. 19) Matton, G.: Arch. int. Pharmacodyn., $110: 472,1957 .-20$ ) Kezdi, P.: Circulat. Res., $11: 145,1962$. 